\title{
STRUKTUR KOMUNITAS LAMUN DI PULAU WANCI, KABUPATEN WAKATOBI, SULAWESI TENGGARA
}

\section{SEAGRASS COMMUNITY STRUCTURE IN THE WANCI ISLAND, WAKATOBI REGENCY, PROVINCE OF SOUTHEAST SULAWESI}

\author{
Nur Ikhsan ${ }^{1}$, Neviaty Putri Zamani ${ }^{2}$, Dedi Soedharma ${ }^{2}$ \\ ${ }^{1}$ Program Studi Ilmu Kelautan, \\ ${ }^{2}$ Departemen Ilmu dan Teknologi Kelautan, \\ Fakultas Perikanan dan Ilmu Kelautan, Institut Pertanian Bogor \\ Korespondensi: nurikhsan08@gmail.com
}

\begin{abstract}
Seagrass is sea plant that is no less important to other coastal ecosystems such as coral reefs and mangroves in terms of physical, ecological, and economic. Indonesia has 12 species of seagrasses from 58 species of seagrasses in the world. Not all regions in Indonesia has the same species seagrasses due to differences in environmental conditions or anthropogenic pressures, a study of seagrass species diversity in Indonesian waters need to be done. This research was conducted to indentify seagrass community structure in intertidal area of Wanci waters, Wakatobi Regency, Southeast Sulawesi Province. Stations of observation was located in seagrass bed area that divided in to four stations. Sampling methods was conducted refers to McKenzie et al. (2001) by using quadratic transect $50 \mathrm{~cm} \times 50 \mathrm{~cm}$. In each the quadratic transect, there was recorded of species, and total of the plant. The result of research showed that there were 7 species of segrasses found in Wanci island waters namely Halophila ovalis, Halodule uninervis, Cymodocea rotundata, Thalassia hemprichii, Enhalus acroides, Thalasodendron, and Syringodium isoetifolium. The highest density of seagrass species was dominated by Thalassia hemprichii, Halodule uninervis, and Cymodocea rotundata. The overall distribution pattern of seagrass species were cluster. There is correlation between environmental parameters and seagrass density. Sand substrate has a high positive correlation to the density of seagrass whereas clay substrate, current velocity, salinity, and temperature had a negative correlation (low to high) to the density of seagrass in Wanci Island waters.
\end{abstract}

Keywords: density, seagrass, species composition, Wanci Island

\begin{abstract}
ABSTRAK
Lamun merupakan tumbuhan laut yang memiliki peran yang tidak kalah penting dengan ekosistem pesisir lainnya seperti terumbu karang dan mangrove baik dari segi fisik, ekologi, dan ekonomi. Indonesia memiliki 12 jenis lamun dari 58 jenis lamun di dunia. Tidak semua wilayah di Indonesia memiliki jumlah jenis yang sama karena perbedaan kondisi lingkungan atau tekanan antropogenik, sehingga perlu ada kajian keragaman jenis lamun di wilayah perairan Indonesia. Penelitian ini bertujuan untuk mengidentifikasi struktur komunitas lamun dan keterkaitan antara kerapatan lamun dan parameter lingkungan di perairan Pulau Wanci, Sulawesi Tenggara. Stasiun pengamatan berada pada daerah padang lamun yang dibagi menjadi 4 stasiun. Metode sampling yang digunakan mengacu pada McKenzie et al. (2001) menggunakan transek kuadrat $50 \mathrm{~cm}$ x $50 \mathrm{~cm}$. Selanjutnya menghitung jumlah tegakan lamun dan mencatat jenis lamun yang ditemukan pada tiap transek kuadrat. Hasil penelitian menunjukkan bahwa ditemukan 7 jenis lamun di perairan Pulau Wanci yaitu Halophila ovalis, Halodule uninervis, Cymodocea rotundata, Thalassia hemprichii, Enhalus acroides, Thalasodendron ciliatum, dan Syringodium isoetifolium dengan kerapatan tertinggi didominasi oleh T. hemprichii, H. uninervis, dan C. rotundata dengan pola sebaran keseluruhan adalah mengelompok. Terdapat keterkaitan antara kerapatan lamun dengan parameter lingkungan, substrat berpasir memiliki korelasi positif yang tinggi terhadap kerapatan lamun sedangkan substrat liat, kecepatan arus, salinitas, dan suhu memiliki korelasi negatif yang rendah sampai tinggi terhadap kerapatan lamun di perairan Pulau Wanci.
\end{abstract}

Kata kunci: kerapatan, komposisi jenis, lamun, Pulau Wanci 


\section{PENDAHULUAN}

Lamun adalah tumbuhan akuatik yang telah beradaptasi untuk bisa bertahan hidupdalam lingkungan perairan. Tumbuhan ini memiliki kedekatan lebih besar dengan tumbuhan darat dibanding tumbuhan laut lainnya seperti alga (Waycott et al. 2006) karena memiliki akar, rhizoma, batang, dan daun seperti tumbuhan (rerumputan) darat pada umumnya (Larkum et al. 2006). Lamun tumbuh subur di laut dan muara perairan dangkal di seluruh dunia (Bjork et al. 2008), seperti daerah pasang surut, estuari, di depan formasi hutan bakau dan sering juga ditemui diterumbu karang (Nontji 2007). Umumnya tumbuh pada habitat berpasir, berlumpur dan berkoral (Kiswara 1992). Kadang-kadang lamun membentuk komunitas yang lebat hingga merupakan padang lamun (seagrass bed) yang cukup luas (Nontji 2007). Kurang lebih ada 58 jenis lamun di seluruh dunia (Azkab 2006) dimana dari keseluruhan jenis tersebut, 12 jenis terdapat di Indonesia (Nontji 2007).

Banyak orang yang memandang lamun sebagai tumbuhan yang tidak memiliki arti. Padahal kenyataannya lamun memiliki peran yang begitu besar. Secara ekonomi misalnya dimanfaatkan sebagai atap rumbia, pupuk, makanan ternak, dan sebagai bahan obat-obatan (Azkab 2006). Secara fisik mampu melindungi pantai dari hempasan ombak (Bos et al. 2007) sehingga mengurangi terjadinya erosi pantai (Peterson et al. 2004). Secara ekologi berperan sebagai tempat memijah (Unsworth et al. 2009), tempat berlindung (Giovannetti et al. 2006; Curtis dan Vincent 2005), dan mencari makan berbagai organisme perairan (Vonk et al. 2008; Azis et al. 2006). Padang lamun juga berperan dalam penyerapan karbon sehingga mampu mengurangi pemanasan global (Duarte et al. 2005). Hasil penyerapan karbon tersebut disimpan dalam bentuk biomassa terutama pada bagian bawah substrat karena dapat tersimpan dalam waktu yang lebih lama dibanding pada bagian atas substrat (Kiswara dan Ulumuddin 2009). Laksmi et al. (2006) juga melaporkan bahwa lamun jenis Thalassia hemprichii mengandung senyawa bioaktif diantaranya sebagai anti bakteri, anti fungi, anti protozoa, dan bahan obat-obatan.

Pulau Wanci merupakan salah satu pulau dari kepulauan Wakatobi, provinsi Sulawesi Tenggara yang potensi lamunnya masih cukup baik. Minimnya kegiatan industri dan pembangunan, disertai penangkapan yang ramah lingkungan merupakan penyebab lamun di perairan tersebut dapat tumbuh dengan baik. Sebagian besar penelitan yang dilakukan di kepulauan Wakatobi yaitu seputar terumbu karang. Padahal terumbu karang dan lamun merupakan ekosistem pesisir yang saling berpengaruh dan sama-sama memiliki peran penting bagi kehidupan. Dalam rangka melengkapi informasi lamun di perairan Indonesia maka penelitan terkait struktur komunitas lamun di perairan Pulau Wanci perlu dilakukan. Penelitan ini diharapkan dapat melahirkan penelitan selanjutnya di lokasi yang sama yang mengkaji lamun lebih dalam lagi.

Penelitian ini bertujuan untuk mengidentifikasi komposisi dan kerapatan jenis lamun di perairan Pulau Wanci, provinsi Sulawesi Tenggara. Manfaat penelitian ini adalah sebagai masukan dalam pengelolaan ekosistem lamun di Kepulauan Wakatobi, serta menjadi dasar bagi penelitian selanjutnya.

\section{METODE PENELITIAN}

\section{Waktu dan lokasi penelitian}

Penelitian ini dilaksanakan pada bulan Oktober-Desember tahun 2014 bertempat di perairan Pulau Wanci, Kabupaten Wakatobi, Provinsi Sulawesi Tenggara. Peta lokasi penelitian dapat dilihat pada Gambar 1.

\section{Alat dan bahan}

Alat yang digunakan dalam penelitian ini adalah alat tulis menulis, meteran gulung, transek kuadrat (modifikasi Seagrass-watch 2001), wadah sampel, kertas label, kamera bawah air, Global Positioning System (GPS), buku identifikasi lamun (Seagrass-watch 2001), termometer, refraktometer, $\mathrm{pH}$ meter, current meter, tali, bola pingpong, dan stopwatch. Adapun bahan yang digunakan adalah lamun dan sampel air.

\section{Prosedur penelitian}

\section{Penentuan stasiun penelitian}

Stasiun pengamatan dibagi menjadi 4 stasiun berdasarkan keberadaan lamun. Stasiun 1 merupakan wilayah yang masih tergolong alami, dimana di lokasi tersebut jauh dari pemukiman penduduk dan 
di sekitar pantainya banyak ditumbuhi vegetasi mangrove jenis Rhizopora, Stasiun 2 berada diantara rumah penduduk, Stasiun 3 berada di sekitar pelabuhan, dan Stasiun 4 berhadapan dengan laut lepas. Posisi dan letak geografis keempat stasiun tersebut secara ringkas disajikan pada Tabel 1 .

\section{Pengambilan data lamun}

Pengamatan lamun dilakukan pada tiap transek kuadrat pada tiap stasiun pengamatan dengan cara menghitung jumlah tegakan lamun dan mencatat jenis lamun yang ditemukan. Identifikasi jenis lamun dilakukan dengan bantuan buku identifikasi lamun yang mengacu pada McKenzie et al. (2001).

Pada tahapan pengambilan sampel, tiap stasiun dibagi menjadi 3 sub stasiun, dimana pada tiap sub stasiun dibentangkan transek garis sepanjang $200 \mathrm{~m}$ yang dipasang tegak lurus garis pantai menuju laut menggunakan roll meter. Pada tiap substasiun terdiri dari 6 transek kuadrat berukuran $50 \mathrm{~cm} \times 50 \mathrm{~cm}\left(0,25 \mathrm{~m}^{2}\right)$. Jarak antara transek kuadrat satu dengan lainnya adalah $20 \mathrm{~m}$ dan jarak antara transek garis satu dengan lainnya adalah $25 \mathrm{~m}$ (Gambar 2).

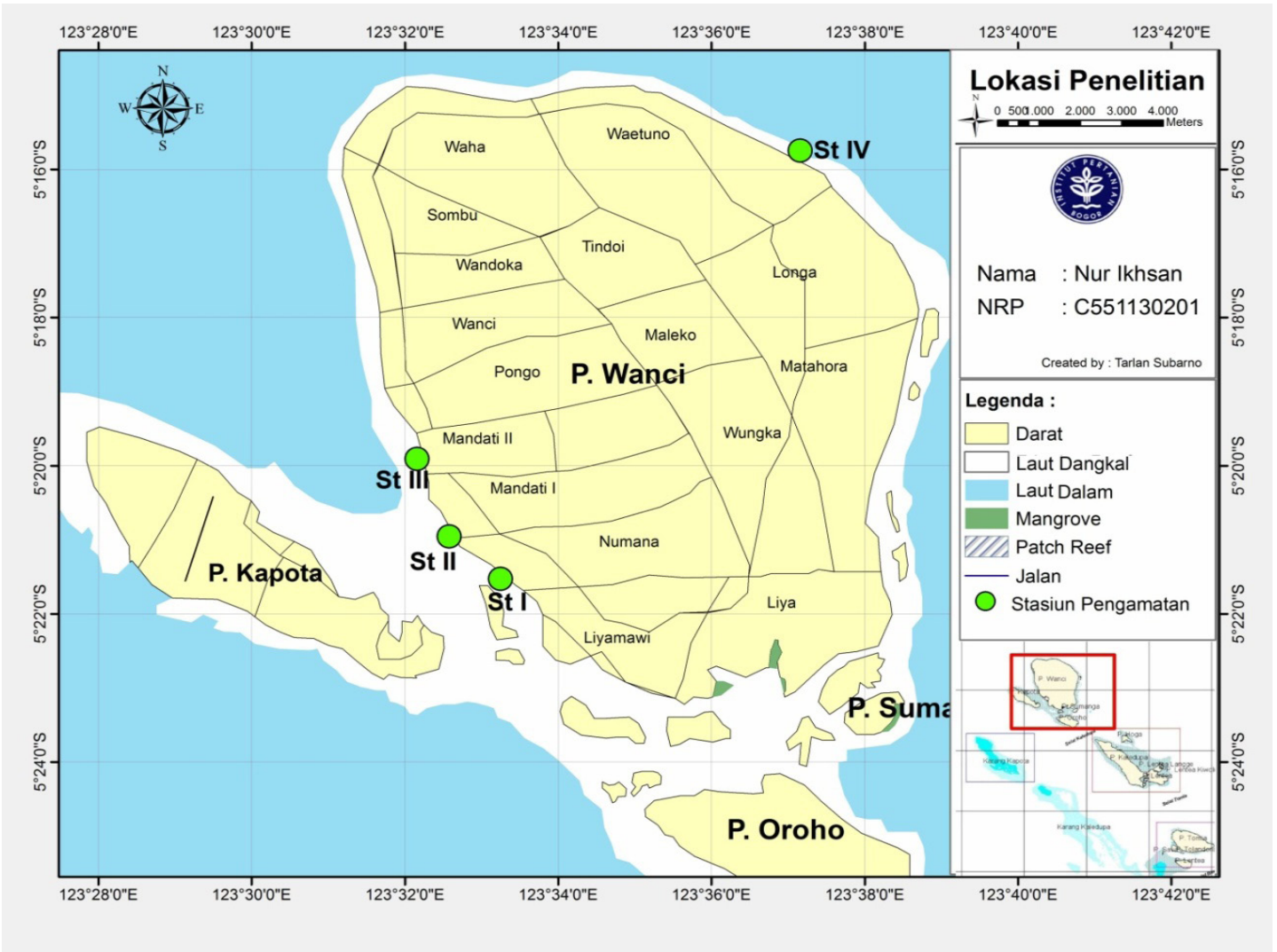

Gambar 1. Peta lokasi penelitian

Tabel 1. Posisi pengambilan sampel tiap stasiun pengamatan

\begin{tabular}{|c|c|c|}
\hline Stasiun & Posisi & Letak Geografis \\
\hline 1 & $\begin{array}{l}\text { Perairan pantai Desa Numana, } \\
\text { Kecamatan Wangi-Wangi Selatan }\end{array}$ & $123^{\circ} 32^{\prime} 58,20^{\prime \prime} \mathrm{BT}$ dan $5^{\circ} 21^{\prime} 11,94^{\prime \prime} \mathrm{LS}$ \\
\hline 2 & $\begin{array}{l}\text { Diantara rumah gantung masyarakat } \\
\text { bajo, Desa Mola Utara, Kecamatan } \\
\text { Wangi-Wangi Selatan }\end{array}$ & 123032’37,68” BT dan 5020’56,20” LS \\
\hline 3 & $\begin{array}{l}\text { Dekat Pelabuhan Panjang Wanci, } \\
\text { Kecamatan Wangi-Wangi Selatan }\end{array}$ & 123032'14,53" BT dan 5020'14,82" LS \\
\hline 4 & $\begin{array}{l}\text { Perairan pantai Desa Waelumu, } \\
\text { Kecamatan Wangi-Wangi }\end{array}$ & 123033'39,53” BT dan 5015’0,90” LS \\
\hline
\end{tabular}




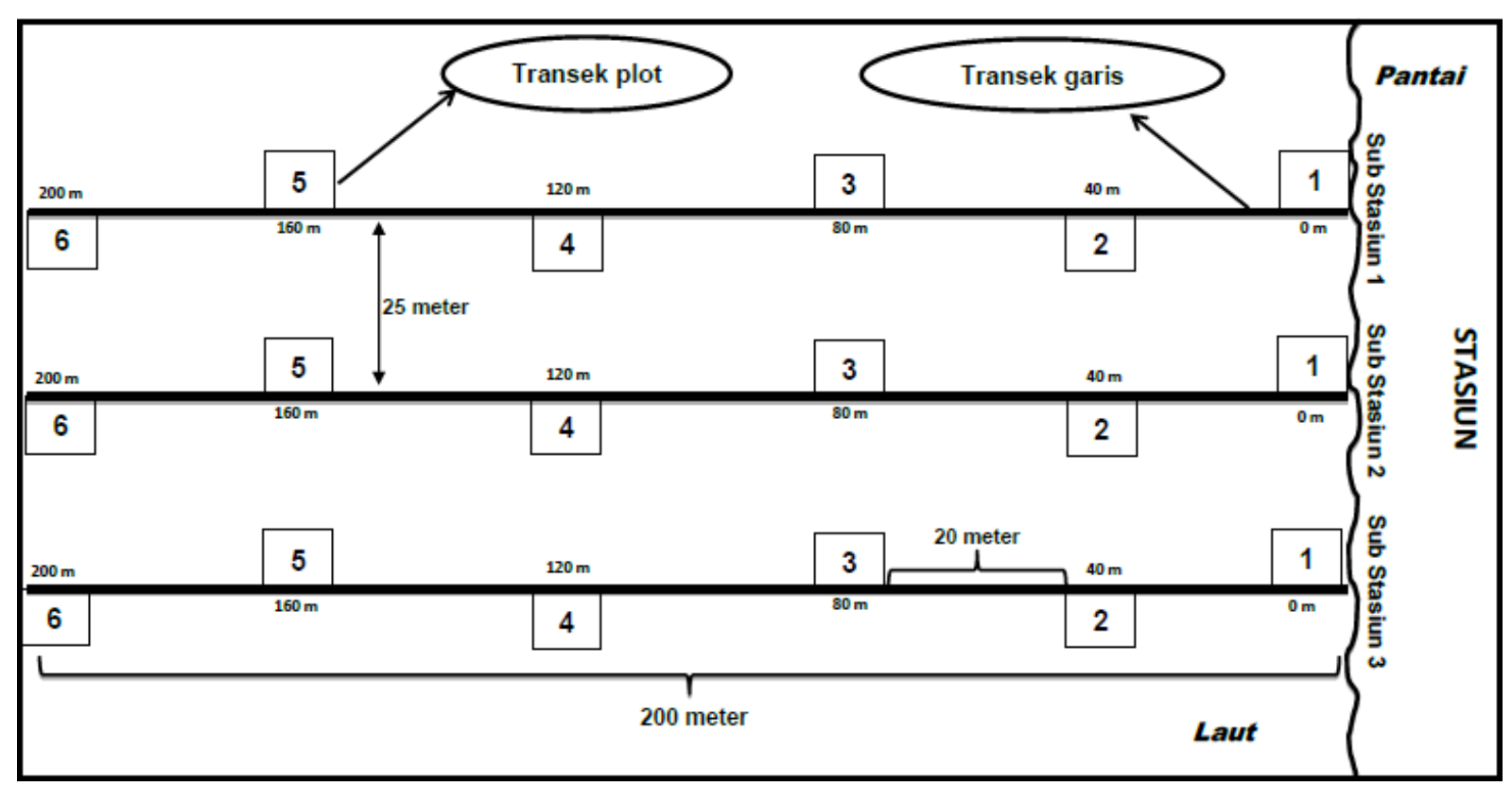

Gambar 2. Contoh skematik penempatan transek pada stasiun pengamatan lamun

Pengukuran parameter fisika-kimia perairan

Dalam rangka mengetahui kondisi perairan yang sesuai bagi kehidupan lamun maka dilakukan pengukuran parameter fisika-kimia perairan. Variabel yang diamati adalah suhu, salinitas, $\mathrm{pH}$, dan kecepatan arus yang diukur secara langsung di lokasi pengamatan (in situ).

\section{Analisis data}

\section{Kerapatan jenis lamun}

Kerapatan jenis lamun dihitung berdasarkan English et al. (1997) sebagai berikut:

$$
X_{i}=n i / A
$$

\section{Keterangan:}

$X i=$ kerapatan jenis ke- $i$ (ind $/ \mathrm{m}^{2}$ )

$n i=$ jumlah total individu jenis ke- $i$ (ind)

$A=$ luas area total pengambilan contoh $\left(\mathrm{m}^{2}\right)$

Pola sebaran jenis lamun

Pola sebaran jenis teripang ditentukan dengan menggunakan Indeks Morisita berdasarkan Khouw (2009) sebagai berikut:

$$
I_{d}=n \frac{\sum x^{2}-\sum x}{\left(\sum x\right)^{2}-\sum x}
$$

dimana:

$I_{d} \quad=$ indeks sebaran Morisita

$n=$ jumlah kuadran pengambilan contoh

$\sum x=$ jumlah individu di setiap kuadran $=$ $x_{1}+x_{2}+\ldots$

$\sum x^{2}=$ jumlah individu di setiap kuadran dikuadratkan $=x_{1}^{2}+x_{2}^{2}+\ldots$.

dengan kriteria:

$I_{d}<1=$ pola sebaran individu jenis bersifat seragam

$I_{d}=1$ = pola sebaran individu jenis bersifat acak

$I_{d}>1$ = pola sebaran individu jenis bersifat mengelompok

Indeks keanekaragaman

Keanekaragaman dihitung dengan menggunakan Indeks Keanekaragaman Shannon-Wiener berdasarkan (Wilhm dan Doris 1986) sebagai berikut:

$$
H^{\prime}=-\sum_{i-1}^{s} p i \log p i
$$

dimana:

$H^{\prime} \quad=$ indeks keanekaragaman ShannonWiener

pi $\quad=n i / N$

ni $=$ jumlah individu jenis ke-i

$N \quad=$ jumlah total individu seluruh jenis

$s \quad=$ jumlah jenis 
dengan kriteria:

$H^{\prime}<1=$ Keanekaragaman jenis rendah

$1<H^{\prime}<3=$ Keanekaragaman jenis sedang

$H^{\prime}>3=$ Keanekaragaman jenis tinggi

\section{Indeks keseragaman}

Nilai indeks keseragaman digunakan untuk menggambarkan komposisi individu tiap spesies yang terdapat dalam suatu komunitas. Indeks keseragaman teripang dihitung berdasarkan Krebs (1989), sebagai berikut:

$$
E=H^{\prime} / H_{\max }
$$

dimana:

$E \quad=$ indeks keseragaman

$H^{\prime} \quad=$ indeks keanekaragaman ShannonWienner

$H_{\max }=\log \mathrm{S}$

$S \quad=$ jumlah jenis

dengan kriteria:

$0,00<\mathrm{E} \leq 0,50=$ komunitas tertekan

$0,50<\mathrm{E} \leq 0,75=$ komunitas labil

$0,75<\mathrm{E} \leq 1,00=$ komunitas stabil

Indeks dominansi

Nilai indeks dominansi digunakan untuk menggambarkan ada tidaknya dominasi suatujenis dalam suatu komunitas, yang dihitung dengan menggunakan indeks dominansi Simpson (Magurran 1988), sebagai berikut:

$$
C=\sum_{i-1}^{s} p i^{2}
$$

dimana:

$C=$ indeks dominansi Simpson $p i=n i / N$

$n i=$ jumlah individu jenis ke-i

$N=$ jumlah total individu seluruh jenis

$s \quad=$ jumlah jenis

dengan kriteria:

$0.00<C \leq 0.50=$ dominansi rendah

$0.50<C \leq 0.75=$ dominansi sedang

$0.75<C \leq 1.00=$ dominansi tinggi

\section{Keterkaitan antara lamun dan parameter lingkungan perairan}

Keterkaitan antara lamun dan parameter lingkungan dianalisis dengan menggunakan dengan menggunakan PCA (Principal Component Analysis) dengan bantuan software ExcelStat 2009. Kuat lemahnya keterkaitan antar variabel tersebut dapat diketahui dengan mengacu pada Abdurahman dan Muhidin (2007) dengan melihat nilai korelasi (R) sebagai berikut:

a. Jika R 0,00 - <0,20 : keterkaitnannya sangat lemah (dianggap tidak ada)

b. Jika $R \geq 0,20-<0,40$ : keterkaitnannya rendah

c. Jika $R \geq 0,40-<0,70$ : keterkaitnannya sedang/cukup

d. Jika $R \geq 0,70-<0,90$ : keterkaitnannya kuat atau tinggi

e. Jika $R \geq 0,90-\leq 1,00$ : keterkaitnannya sangat kuat/tinggi

\section{HASIL DAN PEMBAHASAN}

\section{Parameter fisika-kimia perairan}

Hasil pengukuran rata-rata parameter fisik-kimia perairan Pulau Wanci dapat dilihat pada Tabel 2.

Tabel 2. Parameter fisika-kimia perairan rata-rata pada tiap stasiun pengamatan

\begin{tabular}{lccccc}
\hline \multicolumn{1}{c}{ Parameter } & Stasiun 1 & Stasiun 2 & Stasiun 3 & Stasiun 4 & Baku Mutu \\
\hline Suhu $\left({ }^{\circ} \mathrm{C}\right)$ & $29,67 \pm 0,76$ & $30,33 \pm 0,76$ & $30,67 \pm 0,37$ & $31,00 \pm 0,66$ & $\leq 32$ \\
Salinitas (ppt) & $28,67 \pm 0,37$ & $29,33 \pm 0,37$ & $30,33 \pm 0,37$ & $31,00 \pm 0,66$ & $\leq 34$ \\
$\mathrm{pH}$ & $6,83 \pm 0,19$ & $7,00 \pm 0,33$ & $7,33 \pm 0,19$ & $7,50 \pm 0,46$ & $\leq 8,5$ \\
Arus (m/det) & 0,044 & 0,047 & 0,050 & 0,059 & \\
\hline
\end{tabular}

Keterangan Baku mutu, berdasarkan KepMen LH No. 51 tahun 2004 
Suhu merupakan salah satu parameter fisik perairan yang mempengaruhi kehidupan organisme perairan. Organisme perairan mempunyai toleransi yang berbedabeda terhadap suhu. Menurut Supriharyono (2009) suhu berpengaruh secara tidak langsung terhadap fotosintesis tumbuhan karena beberapa proses metabolisme, seperti respirasi dan pengambilan unsur hara sangat tergantung pada suhu air.

Suhu suatu badan air diantaranya dipengaruhi oleh musim, ketinggian dari permukaan laut, waktu dalam hari, dan penutupan awan. Peningkatan suhu menyebabkan peningkatan kecepatan metabolisme dan respirasi organisme akuatik, sehingga terjadi peningkatan konsumsi oksigen oleh organisme akuatik. Peningkatan suhu juga menyebabkan terjadinya penurunan kadar oksigen terlarut dalam air sehingga kebutuhan oksigen organisme akuatik untuk melakukan proses metabolisme dan respirasi tidak tercukupi (Effendi 2003).

Tumbuhan laut seperti lamun akan mengalami penghambatan pertumbuhan atau mengalami kematian jika suhu suatu perairan terlampau tinggi atau rendah. Berdasarkan hasil pengukuran, terlihat bahwa suhu yang ditemukan pada tiap stasiun pengamatan (Tabel 2) masih tergolong optimum atau sesuai untuk kehidupan lamun.

\section{Salinitas}

Salinitas juga merupakan parameter fisik perairan yang penting bagi kehidupan organisme perairan. Menurut Odum (1996) secara langsung, perubahan salinitas dapat mempengaruhi penyebaran organisme perairan dan secara tidak langsung, dapat merubah komposisi organisme dalam suatu perairan. Menurut Effendi (2003), masukan air tawar dari sungai sangat mempengaruhi nilai salinitas di perairan pesisir. Pada perairan pantai biasanya salinitas rendah akibat pengenceran oleh aliran sungai. Salinitas akan semakin meningkat pada daerah dengan penguapan yang tinggi (Nontji 2007).

Beberapa jenis lamun kemungkinan memiliki toleransi yang berbeda terhadap salinitas perairan. Kondisi salinitas dibeberapa lokasi pengamatan yang berbeda menyebabkan perbedaan sebaran jenis lamun yang tumbuh pada lokasi tersebut seperti Thalasodendron ciliatum yang hanya terdapat di Stasiun 4. Secara keseluruhan, salinitas yang ditemukan pada tiap stasiun pengamatan (Tabel 2) masih tergolong optimum untuk kehidupan lamun.

$p H$

$\mathrm{pH}$ merupakan faktor pembatas bagi organisme yang hidup di suatu perairan. Perairan dengan $\mathrm{pH}$ yang terlalu tinggi atau rendah akan mempengaruhi ketahanan hidup organisme yang hidup di dalamnya (Odum 1996). pH menggambarkan keberadaan ion hidrogen yang terdapat pada suatu perairan. $\mathrm{pH}$ perairan biasanya akan mengalami penurunan ketika suhu rendah akibat kurangnya intensitas matahari, sehingga proses fotosintesis oleh tumbuhan air seperti lamun akan berkurang, menyebabkan rendahnya pemakaian $\mathrm{CO}_{2}$ di perairan. Penurunan $\mathrm{pH}$ juga dapat menyebabkan terhentinya proses nitrifikasi di perairan (Effendi 2003).

Berdasarkan hasil pengamatan, terlihat bahwa nilai $\mathrm{pH}$ yang ditemukan pada tiap stasiun (Tabel 2) masih tergolong optimum bagi kehidupan lamun.

\section{Kecepatan Arus}

Arus merupakan gerakan mengalir suatu massa air yang dapat disebabkan oleh tiupan angin, perbedaan densitas air laut atau dapat pula disebabkan oleh pasang surut (Nontji 2007). Arus berperan sebagai transpor bahan makanan tambahan bagi organisme perairan dan dalam hal pengangkutan bahan buangan.

Dari hasil pengamatan terlihat bahwa kecepatan arus yang terukur di lokasi penelitian berkisar antara 0,0440,059 m/det. Kecepatan arus pada Stasiun 1, Stasiun 2, dan Stasiun 3 tergolong rendah karena berhadapan dengan Pulau Kapota (Tabel 2). Adapun Stasiun 4 memiliki kecapatan arus yang lebih tinggi dari ketiga stasiun tersebut karena berhadapan dengan laut lepas. Secara keseluruhan, kecepatan arus tersebut masih sesuai bagi kehidupan lamun.

\section{Komposisi jenis lamun}

Ditemukan tujuh jenis lamun di perairan Pulau Wanci yaitu Cymodocea rotundata, Halodule uninervis, Thalassodendron ciliatum, Syringodium isoetifolium, Thalassia hemprichii, Enhalus 
acroides, dan Halophila ovalis (Tabel 3). Jenis lamun yang ada di Pulau Wanci tergolong tinggi karena hampir mewakili 12 jenis lamun yang ada di Indonesia. Berbeda dengan hasil penelitian Satrya et al. (2012) yang hanya menemukan 5 jenis lamun di Teluk Banten.

Lamun jenis Cymodocea rotundata, Thalassia hemprichii, dan Halodule uninervis merupakan jenis lamun berukuran besar yang umum ditemukan di setiap stasiun pengamatan dibanding jenis lamun lainnya. Bjork et al. (2008) menjelaskan bahwa keberadaan lamun berukuran besar seperti Cymodocea rotundata dan Thalassia hemprichii di daerah intertidal berhubungan dengan karakter morfologis yang dimilikinya sehingga mampu menoleransi kondisi kekeringan atau meminimumkan tekanan akibat kekeringan.

Perbedaan sebaran jenis lamun tersebut disebabkan perbedaan karakteristik habitat dari tiapjenis lamun yang ditemukan. Lamun yang berukuran besar yaitu Enhalus acroides, Thalassodendron ciliatum, dan Syringodium isoetifolium umumnya dijumpai berada pada daerah yang lebih dalam dan selalu tergenang/terendam air, sedangkan jenis lainnya berada di daerah yang lebih dangkal seperti Halophila ovalis yang hanya ditemukan ditepi pantai. Philips dan Menez (1988) menjelaskan bahwa jenis lamun yang berukuran kecil yaitu Halophila ovalis dan marga Halodule biasa menempati daerah intertidal atau yang lebih dangkal, terutama pada substrat yang lembab. Hal ini disebabkan karakteristik daunnya yang tipis dan fleksibel dapat memudahkannya hidup pada kondisi lingkungan tersebut.

\section{Kerapatan jenis lamun}

Kerapatan rata-rata jenis lamun di lokasi penelitian berkisar antara 2683.208 ind $/ \mathrm{m}^{2}$, dengan kerapatan tertinggi secara keseluruhan didominasi lamun jenis Thalassia hemprichii, Halodule uninervis, dan Cymodocea rotundata (Gambar 3). Jika dibandingan dengan hasil penelitian Satrya et al. (2012) yang melaporkan kerapatan lamun di Teluk Banten adalah 44-193 ind/ $\mathrm{m}^{2}$ maka dapat dikatakan bahwa kerapatan lamun di Pulau Wanci tergolong tinggi.

Perbedaan kerapatan jenis lamun pada keempat stasiun pengamatan kemungkinan bukan disebabkan oleh aktifitas manusia berupa tekanan antropogenik atau kegiatan industri karena masyarakat Pulau Wanci belum memanfaatkan lamun menjadi sesuatu yang bernilai ekonomis dan sebagian besar aktivitas pengolahan di daerah tersebut masih bersifat tradisional sehingga belum mengancam kehidupan lamun.

Penyebab utama perbedaan kerapatan jenis lamun tersebut adalah akibat faktor alam berupa perbedaan topografi dan substrat pada masingmasing lokasi pengamatan karena jenis lamun tertentu memiliki pola adaptasi yang berbeda terhadap faktor alam tersebut. Short dan Coles (2001) menjelaskan bahwa kerapatan lamun dipengaruhi oleh berbagai faktor seperti jenis lamun, kondisi substrat, musim, pasang surut, kekuatan energi gelombang, kandungan bahan organik dalam sedimen serta faktor lingkungan lainnya.

Tabel 3. Jenis lamun yang ditemukan pada tiap stasiun pengamatan

\begin{tabular}{clllll}
\hline \multirow{2}{*}{ Famili } & \multicolumn{2}{c}{ Spesies } & \multicolumn{4}{c}{ Stasiun } \\
\cline { 3 - 6 } & & 1 & 2 & 3 & 4 \\
\hline Potamogetonaceae & Cymodocea rotundata & $\sqrt{ }$ & $\sqrt{ }$ & $\sqrt{ }$ & $\sqrt{ }$ \\
& Halodule uninervis & $\sqrt{ }$ & $\sqrt{ }$ & $\sqrt{ }$ & $\sqrt{ }$ \\
& Syiringodium isoetofilium & - & - & $\sqrt{ }$ & $\sqrt{ }$ \\
& Thalasodendron ciliatum & - & - & - & $\sqrt{ }$ \\
Hydrocharitaceae & Thalassia hemprichii & $\sqrt{ }$ & $\sqrt{ }$ & $\sqrt{ }$ & $\sqrt{ }$ \\
& Enhalus acroides & $\sqrt{ }$ & $\sqrt{ }$ & $\sqrt{ }$ & - \\
& Halophila ovalis & $\sqrt{ }$ & $\sqrt{ }$ & - & - \\
\hline
\end{tabular}

Keterangan:

$\sqrt{ }=$ ditemukan pada lokasi penelitian

- = tidak ditemukan pada lokasi penelitian 


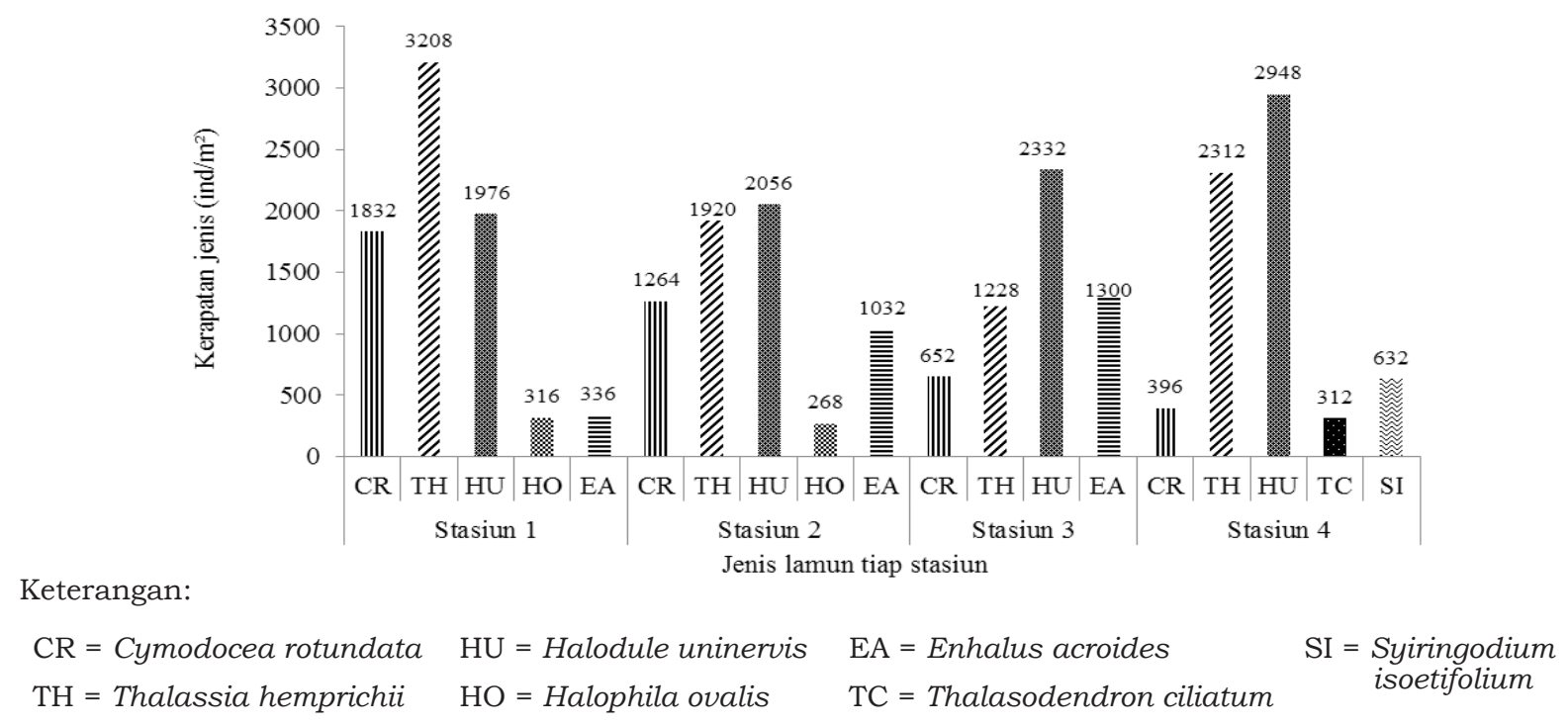

Gambar 3. Kerapatan jenis lamun tiap stasiun pengamatan

Morfologi jenis lamun juga berpengaruh terhadap penutupan lamun karena lamun berukuran besar seperti Thalassia hemprichii, Halodule uninervis, dan Cymodocea rotundata akan memiliki nilai penutupan yang lebih tinggi dibanding lamun berkuran kecil seperti Halodule uninervis atau Halophila ovalis. Tingginya kerapatan lamun jenis Thalassia hemprichii berkaitan dengan kemampuan adaptasinya yang tinggi terhadap semua tipe substrat. Den Hartog (1970) bahwa Thalassia hemprichii hidup dalam semua jenis substrat, bervariasi dari pecahan karang hingga substrat lunak.

Umumnya substrat yang ditemukan pada seluruh lokasi pengamatan didominasi oleh substrat berpasir sehingga mendukung kehidupan jenis lamun yang menyukai kondisi tersebut. Tomascik et al. (1997) juga menjelaskan bahwa Halodule uninervis lebih banyak hidup pada pasir halus hingga kasar di zona intertidal dan subtidal, dan Cymodocea rotundata hidup pada daerah dangkal yang tertutup pasir karang dan mempunyai toleransi yang tinggi pada daerah terbuka (tidak terendam air).

Enhalus acoroides, walaupun mampu beradaptasi terhadap berbagai tipe substrat, jenis ini memiliki kerapatan yang relatif lebih rendah. Kondisi ini berkaitan dengan kedalaman dan topografi perairan Pulau Wanci yang secara keseluruhan landai sehingga lebih banyak area padang lamun yang terbuka saat surut, akibatnya jenis ini hanya tersebar pada padang lamun yang saat surut masih terendam air. Menurut Short dan Coles (2001), Enhalus acroides merupakan jenis lamun yang biasa ditemukan di perairan yang lebih dalam pada substrat berlumpur dan penyebarannya terbatas pada daerah intertidal dan perairan dangkal.

Lamun jenis Halophila ovalis, Thalassodendron ciliatum, dan Syringodium isoetifoliummemilikinilaikerapatan terendah di keempat stasiun penelitian. Hal ini disebabkan, Thalassodendron ciliatum dan Syringodium isoetifolium banyak tumbuh di perairan yang lebih dalam terutama di dekat tubir sedangkan transek yang digunakan untuk pendataan lamun hanya sepanjang $200 \mathrm{~m}$ sehingga peluang terdatanya lebih kecil karena topografi pantai Pulau Wanci umumnya landai dengan panjang \pm 300 $500 \mathrm{~m}$ dari arah pantai menuju tubir atau batas akhir tumbuhnya lamun. Rendahnya kerapatan lamun jenis $S$. isoetifolium juga disebabkan toleransinya yang sempit terhadap kekeringan. Philips dan Menez (1998) menjelaskan, S. isoetifolium hanya mampu memtoleransi kekeringan dalam waktu singkat.

Rendahnya kerapatan lamun jenis Halophila ovalis juga disebabkan lamun jenis ini memiliki penyebaran yang sempit, hanya terbatas di dekat daratan dengan substrat berpasir. Nienhuis et al. (1989) menjelaskan bahwa Halophila ovalis sering terlihat sebagai jenis pembuka yang mendiami substrat pasir.

Kerapatan lamun di perairan Pulau Wanci masih tergolong tinggi. Menurut Danovaro et al. (2002), kelimpahan organisme penghuni padang lamun akan tinggi dengan semakin tingginya kerapatan lamun di suatu perairan. 
Pola sebaran jenis lamun

Berdasarkan hasil pengamatan, terlihat bahwa seluruh jenis lamun yang ditemukan memiliki pola sebaran yang sama yaitu mengelompok (Tabel 4). Hal ini karena dalam transek pengamatan biasanya ditemukan asosiasi antara dua atau tiga jenis lamun. Hal ini juga menjelaskan bahwa jenis lamun yang ditemukan di perairan $P$. Wanci termasuk vegetasi campuran. Hal ini sesuai pernyataan Nienhuis et al. (1989) bahwa padang lamun di perairan Indonesia umumnya termasuk padang lamun vegetasi campuran.

Menurut Herkul dan Kotta (2009), laju pertumbuhan dan persebaran lamun dipengaruhi oleh kualitas air berupa suhu, salinitas, substrat, kecepatan arus, dan derajat keasaman (pH). Misalnya penurunan salinitas akan menurunkan aktifitas fotosintesis tumbuhan lamun.

\section{Keanekaragaman, keseragaman, dan dominansi jenis lamun}

Keanekaragaman jenis lamun (Tabel 5) yang dijumpai pada Stasiun 1 tergolong rendah $\left(\mathrm{H}^{\prime}<1\right)$, Stasiun 2 dan Stasiun 4 tergolong tinggi $\left(\mathrm{H}^{\prime}>3\right)$, dan Stasiun
3 tergolong sedang $\left(1<\mathrm{H}^{\prime}<3\right)$. Tinggi rendahnya tingkat keanekaragaman jenis lamun tersebut dipengaruhi oleh jumlah jenis lamun dan kerapatan atau kerentangan individu/tegakan lamun. Semakin sedikit jumlah jenis lamun dan semakin rentang tegakan lamun maka semakin rendah tingkat keanekaragamannya.

Berdasarkan indeks keseragaman, komunitas lamun pada Stasiun 1 tergolong kategori tertekan $(0,00<\mathrm{E} \leq 0,50)$, sedangkan pada Stasiun 2, Stasiun3, dan Stasiun 4 berada dalam kategori stabil $(0,00<\mathrm{E} \leq$ $0,50)$. Keseragaman suatu komunitas lamun tersebut terkait dengan pola penyebaran dan tingkat dominansi beberapa jenis lamun. Adapun dominansi jenis pada seluruh stasiun pengamatan tergolong rendah $(0,00$ $<\mathrm{C} \leq 0,50)$. Hal ini mengindikasikan bahwa tidak ada jenis lamun yang mendominasi pada wilayah tersebut.

\section{Keterkaitan antara lamun dan parameter lingkungan perairan}

Berdasarkan hasil analisis PCA, diperoleh informasi dari sumbu pertama (F1) sebesar $64,79 \%$ dan sumbu kedua (F2) sebesar dari $25,30 \%$, dengan total informasi sebesar 90,09\% (Gambar 4).

Tabel 4. Pola sebaran jenis lamun pada tiap stasiun pengamatan

\begin{tabular}{clcccccl}
\hline Stasiun & \multicolumn{1}{c}{ Jenis } & $\mathbf{N}$ & $\sum \mathbf{x}$ & $\sum \mathbf{x}^{\mathbf{2}}$ & $\mathbf{( \sum \mathbf { x } ) ^ { \mathbf { 2 } }}$ & Id & Pola Sebaran \\
\hline \multirow{1}{*}{2} & Cymodocea rotundata & 18 & 458 & 38.436 & 209.764 & 3,27 & Mengelompok \\
& Thalassia hemprichii & 18 & 802 & 77.636 & 643.204 & 2,15 & Mengelompok \\
& Halodule uninervis & 18 & 494 & 45.676 & 244.036 & 3,34 & Mengelompok \\
& Halophila ovalis & 18 & 79 & 2.435 & 6.241 & 6,88 & Mengelompok \\
& Enhalus acroides & 18 & 84 & 3.528 & 7.056 & 8,89 & Mengelompok \\
& Cymodocea rotundata & 18 & 316 & 19.970 & 99.856 & 3,55 & Mengelompok \\
& Thalassia hemprichii & 18 & 480 & 57.662 & 230.400 & 4,48 & Mengelompok \\
& Halodule uninervis & 18 & 514 & 49.224 & 264.196 & 3,33 & Mengelompok \\
& Halophila ovalis & 18 & 67 & 2.665 & 4.489 & 10,58 & Mengelompok \\
& Enhalus acroides & 18 & 258 & 15.542 & 66.564 & 4,15 & Mengelompok \\
& Cymodocea rotundata & 18 & 163 & 23.429 & 26.569 & 15,86 & Mengelompok \\
& Thalassia hemprichii & 18 & 307 & 13.505 & 94.249 & 2,53 & Mengelompok \\
& Halodule uninervis & 18 & 583 & 50.743 & 339.889 & 2,66 & Mengelompok \\
& Enhalus acroides & 18 & 325 & 10.489 & 105.625 & 1,74 & Mengelompok \\
4 & Cymodocea rotundata & 18 & 99 & 9.801 & 9.801 & 18 & Mengelompok \\
& Thalassia hemprichii & 18 & 578 & 32.700 & 334.084 & 1,73 & Mengelompok \\
& Halodule uninervis & 18 & 737 & 41.927 & 543.169 & 1,37 & Mengelompok \\
& Thalasodendron ciliatum & 18 & 78 & 6.084 & 6.084 & 18 & Mengelompok \\
& Syiringodium isoetofilium & 18 & 158 & 12.682 & 24.964 & 9,09 & Mengelompok \\
\hline
\end{tabular}


Tabel 5. Keanekaragaman, keseragaman dan dominansi lamun pada tiap stasiun pengamatan

\begin{tabular}{cccc}
\hline Stasiun & Keanekaragaman (H') & Keseragaman (E) & Dominansi (C) \\
\hline 1 & 0,61 & 0,20 & 0,27 \\
2 & 4,22 & 0,90 & 0,22 \\
3 & 2,52 & 0,72 & 0,22 \\
4 & 4,84 & 0,95 & 0,33 \\
\hline
\end{tabular}

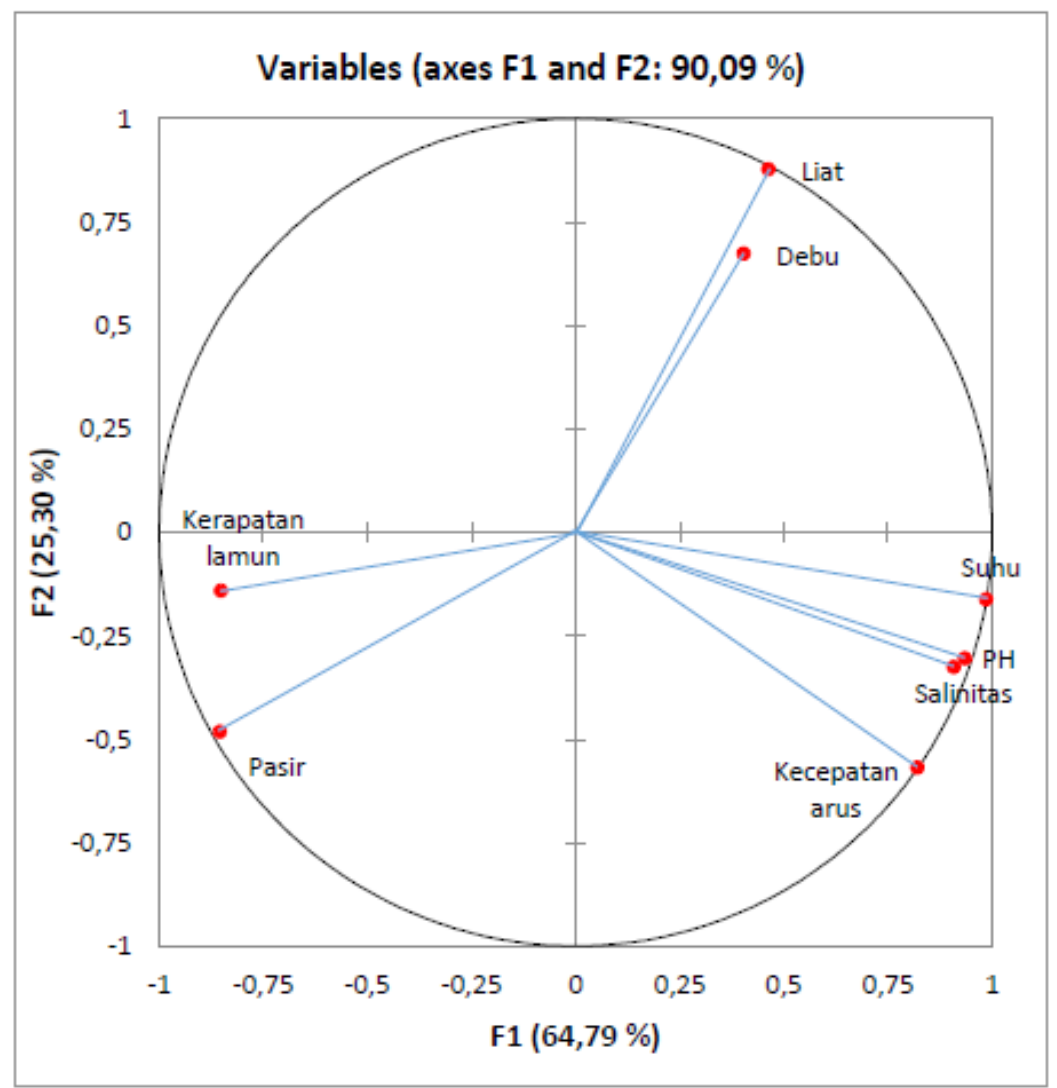

Gambar 4. Analisis komponen utama (PCA), korelasi antara kerapatan lamun dan parameter lingkungan perairan

Terlihat adanya korelasi antara kerapatan lamun dan parameter lingkungan perairan (Gambar 4) sebagai berikut:

- Terdapat korelasi positif (berbanding lurus) yang tinggi antara kerapatan lamun dengan substrat pasir. Artinya semakin tinggi kandungan pasir dalam suatu perairan maka kerapatan lamun juga akan semakin tinggi.

- Terdapat korelasi negatif (berbanding terbalik) yang sedang sampai tinggi antara kerapatan lamun dengan subtrat liat, kecepatan arus, salinitas, dan suhu. Artinya semakin tinggi kandungan substrat liat, kecepatan arus, salinitas, dan suhu di suatu perairan maka kerapatan lamunnya akan semakin berkurang atau rendah.

- Adapun parameter lainnya memiliki korelasi yang kecil atau tidak terlalu berpengaruh terhadap kerapatan lamun di perairan Pulau Wanci.

Dapat dijelaskan bahwa paramater lingkungan yang terdapat di perairan Pulau Wanci memiliki korelasi positif dan negatif yang rendah sampai tinggi. Hampir semua jenis lamun yang ditemui di Indonesia mampu hidup pada substrat berpasir ataupun berlumpur. Kiswara (1992) menjelaskan bahwa Cymodocea rotundata tumbuh pada dasar pasir di dekat pantai yang terbuka saat surut dan jauh dari pantai yang selalu tergenang air, yang tumbuh bersama-sama Thalassia hemprichii. Enhalus acoroides tumbuh pada dasar lumpur, pasir dan pasir berkoral yang selalu tergenang air, yang tumbuh bersamasama Thalassia hemprichii, Syringodium isoetifolium, Cymodocea serrulata, Halodule uninervis, dan Halophila ovalis. Halophila 
ovalis tumbuh pada dasar substrat keras, pasir dan lumpur di daerah terbuka di sepanjang batas pasang surut yang tumbuh bersama-sama Halodule uninervis, Halodule pinifolia, Cymodocea serrulata, Cymodocea rotundata, Thalassia hemprichii, dan Enhalus acoroides. Thalassia hemprichii tumbuh dominan pada dasar pasir ataupun puing karang mati dan dapat tumbuh pada dasar lumpur serta tumbuh bersama-sama Halophila ovalis, Halodule uninervis, dan Cymodocea serrulata.

\section{KESIMPULAN DAN SARAN}

\section{Kesimpulan}

Berdasarkan uraian di atas maka dapat ditarik kesimpulan sebagai berikut:

1. Terdapat 7 jenis lamun yang ditemukan di perairan Pulau Wanci yaitu Halophila ovalis, Halodule uninervis, Cymodocea rotundata, Thalassia hemprichii, Enhalus acroides, Thalassodendron ciliatum, dan Syringodiium isoetifolium.

2. Kerapatan jenis lamun di perairan Pulau Wanci didominasi oleh lamun jenis Thalassia hemprichii, Halodule uninervis, dan Cymodocea rotundata.

3. Lamun yang ditemukan di Pulau Wanci memiliki pola sebaran yang mengelompok.

4. Substrat berpasir di perairan memiliki korelasi yang tinggi terhadap kerapatan lamun sedangkan substrat liat, kecepatan arus, salinitas, dan suhu memiliki korelasi negatif yang rendah sampai tinggi terhadap kerapatan lamun di perairan Pulau Wanci.

\section{Saran}

Perlu ada penelitian yang khusus mengkaji biota-biota penghuni padanglamun di perairan Pulau Wanci sebagai pelengkap informasi dari penelitian-penelitian sebelumnya dan perlu ada penelitian sejenis di perairan Pulau Kaledupa, Pulau Tomia, dan Pulau Binongko sehingga dapat dijadikan sebagai pembanding potensi lamun di Kepulauan Wakatobi.

\section{DAFTAR PUSTAKA}

Abdurahman M, Muhidin AS. 2007. Analisis Korelasi, Regresi, dan Jalur dalam Penelitian. Bandung: CV Pustaka
Setia.

Azkab MH. 2006. Ada Apa dengan Lamun. Majalah Semi Populer Oseana. 31(3): 45-55.

Azis A, Bujang JS, Zakaria MH, Suryana Y, Ghaffar MA. 2006. Fish Communities from Seagrass Bed of Merchang Lagoon, Trengganu, Penninsular Malaysia. Coast Mar Sci. 30(10): 268-275.

Bjork M, Short F, Mcleod E, Beer S. 2008. Managing Seagrasses for Resilience to Climate Change. IUCN Resilience Science Group Working Paper SeriesNo 3. IUCN, Gland, Switzerland.

Bos AR, Bouma TJ, de Kort GLJ, van Katwijk MM. 2007. Ecosystem Engineering by Annual Intertidal Seagrass Beds: Sediment Accretion and Modification. East Coast Shelf Sci. 74: 344-348.

Curtis JMR, Vincent ACJ. 2005. Distribution of Sympatric Seahorse Species along A Gradient of Habitat Complexity in A Seagrass Dominated Community. Mar Ecol Prog Ser. 291: 81-91.

Danovaro R, Gambi C, Mirto S. 2002. Meiofaunal Production and Energy Transfer Efficiency in a Seagrass Posidonia oceanica Bed in the Western Mediterranean. Mar. Ecol. Prog. Ser. 234: 95-104.

Den Hartog C. 1970. Structure, function and classification in seagrass communities. in: McRoy CP, Helfferich C. (ed). Seagrasses ecosystem: A scientific perspective. New York: Marcel Dekker, Inc. hlm 89-121.

Duarte CM, Middelburg JJ, Caraco N. 2005. Major Role of Marine Vegetation on the Oceanic Carbon Cycle. Biogeo Sciencec. 2: 1-8.

Effendi H. 2003. Telaah Kualitas Air bagi Pengelolaan Sumber Daya Lingkungan Perairan. Yogyakarta: Kanisius.

English SC, Wilkinson, Baker V. 1997. Survey Manual for Tropical Marine Recourses. Australian Institute of Marine Science. Townsville.

Giovannetti E, Montefalcone M, Bianchi CN, Morri C, Albertelli G. 2006. Structural Variability of the Epiphytic Community in a Posidonia oceanica Meadow (Ligurian Sea, NW Mediterranean). Biol Mar Medit. 13(4): 145-148.

Herkul K, Kotta J. 2009. Effects of Eelgrass (Zostera marina) Canopy Removal 
and Sediment Addition on Sediment Characteristics and Benthic Communities in the Northern Baltic Sea. Mar. Ecol. 30: 74-82.

Kiswara W. 1992. Vegetasi Lamun (seagrass) di Rataan Terumbu Pulau Pari, Pulau-Pulau Seribu, Jakarta. Makalah diajukan dalam seminar ilmiah nasional peringatan Lustrum VII Fakultas Biologi Universitas Gadjah Mada, Yogyakarta, 20-21 September, 1990. Balitbang Biologi, Puslitbang Oseanologi-LIPI. Jakarta. 25: 31-49.

Khouw AS. 2009. Metode dan Analisa Kuantitatif dalam Bioekologi Laut. Pusat Pembelajaran Pengembangan Pesisir dan Laut. Jakarta.

Kiswara W, Ulumuddin YI. 2009. Peran Vegetasi Pantai dalam Siklus Karbon Global: Mangrove dan Lamun sebagai Rosot Karbon. Workshop Ocean and Climate Change. Laut sebagai Pengendali Perubahan Iklim: Peran Laut Indonesia dalam Mereduksi Percepatan Proses Pemanasan Global. Bogor 4 Agustus 2009.

Krebs CJ. 1989. Ecological Methodology. Harper and Row Publisher. New York.

Laksmi V, Goel AK, Srivastava MN, Kulshreshta DK, Raghubir R. 2006. Bioactivity of Marine Organism: Part IX-Screening of Some Marine Flora from Indian Coasts. Ijeb. 44: 137141.

Larkum AWD, Orth RJ, Duarte CM. 2006. Seagrasses: Biology, Ecology and Conservation. Springer. $690 \mathrm{hlm}$.

Seagrass-wacth. 2001. Manual for Mapping and Monitoring Seagrass Resources by Community (Citizen) Volunteers. QFS, NFC, Calms.

Magurran AE. 1988. Ecological Diversity and Its Measurement. Princetown Press. New Jersey.

McKenzie LJ, Campbell SJ, Roder CA. 2001. Seagrass-Watch: Manual for Mapping and Monitoring Seagrass Resources by Community (Citizen) Volunteers. QFS, NFC, Calms. 100 hlm.

Menteri Negara Lingkungan Hidup. 2004. Keputusan Menteri Negara Lingkungan Hidup tentang Baku Mutu Air Laut untuk Biota Laut. Jakarta: KEP No. 51/
MENLH/I/2004. 8 April 2004.

Nienhuis PH, Coosen J, Kiswara W. 1989. Community Structure and Biomass Distribution of Seagrasses and Macrofauna in the Flores Sea, Indonesia. Sea Research. 23(2): 197214.

Nontji A. 2007. Laut Nusantara. Jakarta: Djambatan.

Odum EP. 1996. Dasar-dasar Ekologi. Yogyakarta: Gadjah Mada University Press.

Peterson CH, Luettich Jr, Micheli F, Skilleter GA. 2004. Attenuation of Water Flow Inside Seagrass Canopies of Differing Structure. Mar Ecol Prog Ser. 268: 81-92.

Philips RS, Menez EG. 1988. Seagrasses. Washington D.C: Smithsonian Institution Press.

Satrya C, Yusuf M, Shidqi M, Subhan B, Arafat D, Anggraeni F. 2012. Keragaman Lamun di Teluk Banten, Provinsi Banten. Jurnal Teknologi Perikanan dan Kelautan. 3(1): 29-34.

Short FT, Coles R. 2001. Global Seagrass Research Methods. The Netherlands: Elsevier Publishing.

Supriharyono. 2009. Konservasi Ekosistem Sumberdaya Hayati. Yogyakarta: Pustaka Pelajar.

Tomascik T, Mah AJ, Nontji A, Moosa MK. 1997. The Ecology of the Indonesian Seas. The Ecology of Indonesia Series. Vol VIII. Singapore: Periplus Edition (HK) Ltd.

Unsworth RKF, Garrard SL, De Leon PS, Cullen LC, Smith DJ, Sloman KA, Bell JJ. 2009. Structuring of IndoPacific Fish Assemblages Along the Mangrove-seagrass Continuum. Aquat Biol. 5: 85-95.

Vonk JA, Christianen MJA, Stapel J. 2008. Redefining the Trophic Importance of Seagrass for Fauna in Tropical IndoPACIFIC Meadows. EastCoast Shelf Sci. 79: 653-660.

Waycott M, Collier C, McMahon K, Ralph P, McKenzie L, Udy J, Grech A. 2006. Vulnerability of Seagrasses in the Great Barrier Reef to Climate Change. Department of Primary Industries and Fisheries, Queensland.

Wilhm JL dan Doris TC. 1986. Biologycal Parameter for Water Quality Criteria. BioScience. 18(6): 477-481. 